\title{
The Impact of Economic, Social And Political Globalization On Economic Growth: Evidence From BRICS-T Countries*
}

\author{
Ekonomik, Sosyal ve Politik Küreselleşmenin Ekonomik Büyüme Üzerindeki Etkisi: BRICS-T Ülkeleri \\ Için Bulgular
}

\author{
Murat TEKBAŞ ${ }^{a *}$ \\ ${ }^{a}$ Öğr.Gör.Dr. Afyon Kocatepe Üniversitesi, Bayat MYO Dış Ticaret Bölümü, Afyon/TÜRKIYE \\ ORCID: 0000-0003-2589-2482
}

\section{A K A L E B İLG İ S İ}

Makale Geçmişi:

Başvuru tarihi: 17 Eylül 2020

Kabul tarihi: 11 Ocak 2021

Anahtar Kelimeler:

Ekonomik küreselleşme,

Sosyal ve Politik küreselleşme,

Ekonomik Büyüme

\section{A R T ICLE INFO}

\section{Article History:}

Received September 17, 2020

Accepted January 11, 2021

\section{Keywords:}

Economic Globalization,

Social and Political Globalization,

Economic Growth

\section{ÖZ}

Bu çalıșmanın temel amacı, BRICS-T ülkelerinde ekonomik büyüme ile ekonomik, sosyal ve politik küreselleşmenin uzun dönemli ilişkisini 1990-2014 yıllarını kapsayan dönem için panel veri analizi yöntemlerini kullanarak analiz etmektir. Cobb-Douglas üretim fonksiyonuna dayalı olarak kurulan modelin ampirik sonuçlarına göre, sermaye birikiminin ve ekonomik, sosyal, politik küreselleșmenin ekonomik büyüme üzerinde pozitif etkili olduğu görülmektedir. Dumitrescu-Hurlin Panel Granger Nedensellik testi sonuçları ise sermaye birikimi ve politik küreselleșme ile ekonomik büyüme arasında çift yönlü nedensellik ilișkisi olduğunu göstermektedir. Ayrıca ekonomik ve sosyal küreselleşmeden ekonomik büyüme doğru tek yönlü nedensellik ilişki tespit edilmiştir. Bu doğrultuda BRICS-T ülkelerinin ekonomik, sosyal ve politik küreselleşme seviyelerini artırmaları ekonomik büyüme performansları üzerinde olumlu etki oluşturabileceği değerlendirilmektedir.

\begin{abstract}
A B S T R A C T
The main purpose of this study is to analyze the long-term relationship between economic growth and economic, social and political globalization in BRICS-T countries by using panel data analysis methods for the period covering the period 1990-2014. According to the empirical results of the model based on the CobbDouglas production function, it is seen that capital accumulation and economic, social and political globalization have a positive effect on economic growth. Dumitrescu-Hurlin Panel Granger Causality test results show that there is a bidirectional causality relationship between capital accumulation and political globalization and economic growth. In addition, a one-way causality relationship from economic and social globalization to economic growth has been determined. Accordingly, it is considered that the BRICS-T countries' increasing their economic, social and political globalization levels may have a positive effect on their economic growth performances.
\end{abstract} *This study was produces from the authors's dissertation entitled "The Investigation of the Relationship between Globalization and
Economic Growth in BRICS-T Countries in different dimensions".

\footnotetext{
* Sorumlu yazar/Corresponding author
}

e-posta:mtekbas@aku.edu.tr 


\section{GENIŞLETILMIŞ ÖZET}

Küreselleşme ülkeler ve topluluklar arasındaki ilişkiyi yeniden şekillendiren dinamik bir süreç olarak değerlendirilmektedir. Küreselleşmenin ekonomik, sosyal ve politik açıdan etkili olduğu ve bu etkinin zamanla arttığı görülmektedir. Ekonomik küreselleşme kapsamında ilk olarak ülkeler arasındaki ticarete engel olan tarife, kota, gümrük vergisi, ithalat yasakları gibi uygulamaların en aza indirerek ticari küreselleșme gerçekleştirilmektedir. İkinci olarak çok uluslu şirketler sayesinde üretimin farklı ülkelerde yapılması ve yönetim, pazarlama vb. faaliyetlerin küresel ölçekte gerçekleștirilmesi üretimin küreselleșmesi olarak kabul edilmektedir. Üçüncü olarak ise finansal kaynaklara sahip olan ülkelerin ellerindeki fazla fonları, fon eksiği olan ülkelere aktarmasıyla finansal küreselleşme hareketlerinin oluştuğu görülmektedir. Sosyal küreselleşme ile toplumların etkileșimini artıran internet, iletișim, medya unsurlarının arttığı ve buna bağlı olarak küresel anlamda toplumların ortak kültür, ortak tüketim alışkanlıklarına sahip olmaya başladığı yeni bir toplumsal yapı oluşmaktadır. Diğer bir küreselleşme boyutu olan politik küreselleşme ise, ülkelerin siyasi olarak ilişkilerin artırıldığı ikili ya da çoklu anlaşmalar, uluslararası kuruluşlara üyelikler, uluslararası kuruluşlar altında birlikte hareket edilmesi şeklinde gerçekleşmektedir. Bu anlamda küreselleşmenin ülke, toplum ve birey açısından çok yönlü bir etki alanı sahip olduğu gözlemlenmektedir.

Küreselleşme konusunda gelişmiş ülkelerin sahip oldukları üretim teknolojisi, finansal kaynaklar, yetişmiş insan kaynakları vb. gibi faktörler açısından daha avantajlı olduğu kabul edilmekle birlikte son yıllarda gelişmekte olan ülkelerin ekonomik büyümelerinde de etkili olduğu görülmektedir. 2001 yılında Goldman-Sachs için Jim O'Neill tarafından hazırlanan raporda dünya ekonomisinde yaşanan gelişmeler ele alınmış ve BRICS ülkelerinin gelecek yıllarda dünya ekonomisinde önemli bir yere sahip olacağı belirtilmiştir. Buradan hareketler çalışmamız BRICS ülkeleri ve son yıllarda bu ülkelere yakın bir gelişme sağlayan Türkiye'yi kapsamaktadır. Çalışmada 1990 - 2014 yılları arasındaki dönem için BRICS-T ülkelerinde ekonomik, sosyal ve politik küreselleşmenin ekonomik büyüme üzerindeki etkisi panel veri analiz yöntemleriyle araştırılmıştır. Söz konusu ülkelerin gelişiminde çok sayıda faktörün etkili olmasının yanında BRICS-T ülkelerinin sahip oldukları nüfus açısından sosyal küreselleşme, elde edilen ekonomik başarılar açısından ekonomik küreselleşme, uluslararası birlikteliklerde yer alma açısından politik küreselleşmenin ekonomik büyüme üzerindeki etkisinin incelenmesinin önemli olduğu değerlendirilmektedir. Bu kapsamda uygulanan FMOLS katsayı tahmincisi sonucunda elde edilen bulgular BRICS-T ülkelerinde ekonomik, sosyal ve politik küreselleşmenin ekonomik büyüme üzerinde pozitif etkili olduğunu göstermektedir. Ayrıca elde edilen sonuçlar sosyal küreselleşmenin ekonomik büyüme üzerinde en yüksek etkiye sahip olduğunu göstermektedir. Çalışmada ayrıca küreselleşme boyutlarının ekonomik büyüme üzerindeki etkisi FMOLS katsayı tahmin yöntemiyle 3 farklı model ile ülkeler için ayrı ayrı araştırılmıştır. Bulgular model I için kişi başına düşen sermaye ve ekonomik küreselleşmenin Brezilya, Rusya ve Güney Afrika'da pozitif etkili olduğu, Türkiye, Hindistan ve Çin'de ise istatistiki olarak anlamlı bir etki olmadığını göstermektedir. Bunun Hindistan ve Çin'de uygulanan ticaret engelleri, kota, gümrük vergiler ve ithalat yasakları gibi devlet politikalarından kaynaklandığı değerlendirilmektedir. Model II için Türkiye, Brezilya, Güney Afrika ve Rusya'da sosyal küreselleşmenin pozitif etkili olduğu sonuçları elde edilmiştir. Çin ve Hindistan da ise sonuçların istatistiki olarak anlamlı olmadığı sonucuna ulaşılmıștır. Son olarak Model III sonuçlarında ise politik küreselleşmenin ekonomik büyüme üzerinde en yüksek etkiye sahip olduğu ülkenin Brezilya ve Türkiye olduğu görülmektedir. Çalışmada değişkenler arasındaki ilişkinin incelendiği Dumitrescu-Hurlin panel granger nedensellik testi sonuçlarında ise ekonomik ve sosyal küreselleşmeden ekonomik büyümeye doğru tek yönlü nedensellik olduğu, politik küreselleşme ile ekonomik büyüme arasında ise çift yönlü nedensellik ilişkisi olduğu sonuçlarına ulaşılmıştır.

Analizler sonucunda ülkeler için elde edilen sonuçlar kapsamında Brezilya'nın küreselleşmeden pozitif etkilendiği görülmekle birlikte ülke içerisindeki olayların bu olumlu durum üzerinde etkili olabileceği değerlendirilmektedir. Brezilya'nın küreselleşme politikalarını hayata geçirebilmesi için öncelikle siyasi istikrarı sağlaması gerekli olduğu düşünülmektedir. Siyasi istikrar ve güçlü yönetimle öncelikle ülkenin uluslararası birlikteliğin sağlanabilmesi için ihtiyaç duyacağı havalimanı, liman ve otoyol yatırımlarının yapılması gerekmektedir. Yapılan altyapı yatırımlarından sonra yeni teşvik programları hayata geçirilmeli bunun sonucunda bölgesel gelişmişlik düzeyinin azaltılarak üretimin tüm ülkede yaygınlaşması sağlanmalıdır. Sonuçlar Rusya açısından değerlendirildiğinde, ülkenin sahip olduğu petrol ve doğalgaz kaynaklarının, ihracatında önemli bir yer tuttuğu görülmektedir. Bu durum doğal kaynaklara sahip olmayan ülkelerin kendisi ile ticaret yapmasına ve ekonomik küreselleșmenin artmasını sağlamaktadır. Dolayısıyla Rusya, genel olarak küreselleșmeden olumlu etkilenen, bir ülke olarak karșımıza çıkmaktadır. Ancak büyümedeki olumlu durum devam ederken değerlendirilmesi gereken husus ekonomik büyümenin petrol ve doğalgaz fiyat artışları temelinde gerçekleștiğidir. Buradan hareketle Rusya'nın üretim konusunda sektörel olarak zenginleșmeye, üretilen mal ve hizmetlerde ise çeşitlendirmeye, ülkede girişimci iklimi oluşturma yönünde çaba göstermesi gerekmektedir. Son yıllarda ekonomik açıdan önemli başarılar elde eden Çin ve Hindistan'ın küreselleşmeden beklenilen ölçüde yarar sağlayamadıkları görülmektedir. Bu durumun oluşmasının nedeni küreselleşme göstergesi olarak çalışmada kullanılan KOF endeksinin, ticari açılık, finansal gelişmişlik, ithalat ve ihracat gibi küreselleşme göstergelerinden farklı olarak ekonomik faaliyetleri bir bütün olarak değerlendirmesidir. KOF küreselleşme endeksi kapsamında dış ticaret, doğrudan yabancı yatırım, portföy yatırımları ve yabancılara gelir ödemeleri mevcut akımlar olarak değerlendirilirken, gizli ithalat engelleri, ortalama gümrük tarifeleri, uluslararası ticaret vergileri ve sermaye hesabı kısıtlamaları gibi unsurlar kısitlamalar olarak toplu bir değerlendirmeye tabi tutulmaktadır. Buradan hareketle Çin ve Hindistan'ın ihracat ve ülkeye yabancı sermaye çekilmesinde yakaladığı başarı karşısında uyguladıkları gümrük tarifeleri ve vergiler küreselleşme endeksinde olumsuz etkiye neden olmaktadır. Çin ve Hindistan'ın ihracatta elde ettikleri başarılara rağmen ekonomik ve kurumsal yapılarının yeterince geliştirilmemesi nedeniyle genel olarak küreselleşmeden istenilen faydayı sağlayamamaktadırlar. Afrika kıtasında en önemli ülkelerden biri olan Güney Afrika, uzun süre yaşanan ırk ayrımına dayalı uygulamaların son bulmasıyla ekonomik, sosyal ve politik açıdan önemli başarılar elde etmektedir. Ülke, uluslararası ve bölgesel birliktelikler kurarak etki alanını genişletip dış ticaretini artırmayı amaçlamaktadır. Ülkenin küreselleşme sürecinde kambiyo rejiminde yaşanan değişim ekonomik anlamda uygulanan liberal politikaların gerisinde kalmış, ülkede halen döviz giriş ve çıkışlarına yönelik mevzuatlar tam serbest hale gelmemiştir. Turizm sektörünün de son yıllarda ülkenin milli gelirinde ortalama \% 8-10 oranlarında paya sahip olduğu görülmektedir. Turizm sektörünün ülkenin sosyal küreselleşme ve istihdam sağlama açısından önemli olduğu düşünülmektedir. Güney Afrika'nın küreselleşmeden pozitif etkilendiği görülmekte olup, bu durumun daha iyi noktaya gelebilmesi için gelişmişlik seviyesinin tüm ülkeye yayılması, kambiyo rejiminde serbestleşmenin sağlanması önemli görülmektedir. BRICS ülkeleriyle birlikte son yıllarda dünya ekonomisinde dikkat çeken Türkiye, genel olarak küreselleşmeden olumlu etkilenen bir ülke olmasına karşılık, ekonomik küreselleşmeden beklenen etki incelenen dönem kapsamında görülmemektedir. Bu durumun önemli bir nedeni Türkiye'nin ihtiyaç duyduğu finansal kaynakların portföy yatırımı olarak gerçekleşmesidir. Ülke içinde ya da dünyada yaşanan gelişmeler neticesinde portföy yatırımlarında yaşanan hareketliliğin olumsuz etkiler oluşturduğu değerlendirilmektedir. Politika yapıcıların doğrudan yabancı yatırımların artırılması amacıyla teşvik politikaları geliştirmesi önemli görülmektedir. Elde edilen sonuçlar ülkenin ekonomik büyümesine katkı sağlayacak en önemli küreselleşme boyutunun politik küreselleşme olduğunu göstermektedir. Bu doğrultuda 2002 yılından itibaren Avrupa Birliği ile ilişkilerin artması ve yeni bölgesel birliktelikler oluşturulması politik yönden ülkenin etki alanını genişleteceğini göstermektedir. 


\section{Introduction}

Globalization can be explained by two general definitions within the context of processes and structures that indicate relationships in a global sense. The first of these definitions is process globalization and it is explained that as a result of new developments in the fields of communication, transportation, technology and science, international, economic, commercial, financial and accelerating social relations it spread all over the world and thus the whole humanity is aware of each other faster and more affected by each other. The second is structural globalization, and it is defined as the global convergence that occurs as a result of the impact of these processes on the borders, politics, socio-cultural structures, legal processes and economic conditions of nation-states (Gözen, 2004, p. 14). In the process of global convergence, it is seen that globalization takes place in three dimensions and it is accepted that the systems formed on these dimensions together form the global system. Although it is not possible to distinguish these dimensions from each other with definite lines, they are evaluated separately in the general framework.

The first of the globalization dimensions constituting the global system is economic globalization (hereafter EG). The sub-factors that enable EG are realized in three different ways. The first sub-factor that provides EG is the globalization of trade. The globalization of trade, is to ensure that international trade is conducted freely within the framework of certain rules by abolishing protective measures such as tariffs, quotas, customs duties and import bans. With the globalization of production, which is the second sub-factor, mobility of production sub-factors is ensured and countries aim to produce more, more-cheaper and more profitable production. Multinational companies have been the ones that have led the globalization of production worldwide. Although multinational companies still have an important place in the world economy, they act as global companies by organizing their production, marketing and management in different countries. The third sub-factor that enables EG is the transfer of portfolio investments to the countries in need by the financially rich countries in the form of foreign direct investments. The applications made within the scope of these three sub-factors enable EG by providing trade, production and financial resources to move globally (Doğan, 2017, p. 22).

The second sub-factor that constitutes globalization is social globalization (hereafter SG) based on socio-cultural interaction of societies with each other. SG aims to unite societies around a common global culture without leaving their own cultures. In this sense, the interaction between societies has increased with the increasing communication opportunities as a result of technological developments. In addition, the widespread use of the Internet and international media elements has brought cultural rapprochement to higher levels. In this direction, a global social structure has been established in which countries have eliminated their differences in many subjects such as common language, common culture and common consumption habits (Dreher, 2006, p. 1093).

The third of the sub-elements of globalization is political globalization (hereafter PG) where political unity is aimed. PG is the practice of increasing the relations of countries with each other and acting in the framework of transnational organizations, establishments and unity in the international arena. With PG, it is aimed for countries to act together politically and benefit from each other mutually (Tekbaş, 2019, p. 136).

The effect of globalization on the economic growth of countries, in which we evaluate different dimensions, has been the subject of many studies in the economic literature after the 90s. Although it is seen that studies generally focus on developed countries that adapt to globalization more quickly, it is seen that the effect of globalization on developing country economies has been investigated since the 2000s. BRICS-T countries cover $65 \%$ of the world 
population, which is 7.6 billion people (Word Bank). In addition, the $20 \%$ share of BRICS-T countries in world trade, which was approximately $\$ 19$ trillion in 2019, shows that these countries are important countries for the world economy (WTO). due to significant population owned in China and India have the highest production facility, South Africa, Russia and Brazil's plenty to have natural resources, resources owned by Russia and Brazil, engineering and balancing with advanced human resources from scientific maintenance, Turkey 's geopolitical position and logistical facilities show the development potential of these countries (Güney, 2017) It is evaluated that BRICS-T countries, which are more globalized compared to developed countries, can increase their production levels by using their production factors effectively and efficiently, and they can be successful globally thanks to globalization. In this direction, it is thought that examining the effect of economic, social and political globalization levels of BRICS-T countries, which have been developing economically since the 2000s, on economic growth can be a guide for countries to achieve their economic growth targets.

It is seen that EG, SG and PG levels of BRICS-T countries increased between 1970 and 2014 and economic growth increased significantly. However, there are different factors that affect the economic growth provided by countries along with globalization (Güney, 2017, p. 26). In this direction, the effect of economic, SG and PG on the economic growth of the countries will be examined in the period between 1990 and 2014, when common data of BRICS-T countries are available. The first part of the study, which is an introduction, will provide general information on EG, SG and PG. In the second part of the study, literature section will give brief information about the studies and results of globalization and economic growth. In the third section, data, model and methodology will be explained. In the fourth section, the stationarity of the series will be examined using panel unit root tests. After determining the stationarity of the series, the cointegration relationship between the variables will be investigated by Pedroni (1999-2004) and Kao (1999) cointegration tests. The direction and coefficient of the cointegration relationship between the variables will be analyzed with the FMOLS (2000) method. In addition, the causality relationship between the variables will be examined by panel causality test. In the last section, the results obtained will be evaluated and suggestions will be made about the policies that should be implemented.

\section{Literature review}

When the existence literature is reviewed, it is observed that there are many studies on the subject of globalization and economic growth. The variables used as indicators of globalization vary in the studies. In the studies, it is seen that the countries that are included in the globalization process are predominantly late, and the study periods cover the period between 1960 and 2016. In Table 1, brief information is given about the studies using trade openness, openness, financial development, import, export, foreign direct investment and economic freedom as indicators of globalization.

In Table 1, Yaprakli (2007), Kiran and Gumus (2011), Manva and Wijeweera (2016) and Kartal and Acaroglu (2017) used trade openness and financial development as an indicator of globalization and they concluded that there is a positive connection between trade openness and economic activities. Ali and Imai (2015) and Gövdere and Can (2016) used the openness variable and found that openness increases economic growth. Kıran and Gümüş (2011) and Ali and Imai (2015) conducted studies using the financial development variable and concluded that financial development positively affected economic growth. . In the study conducted by Afzal (2007) and Gövdere and Can (2016), it was observed that there was no significant relationship between financial development and economic growth. Neto and Viega (2013) concluded that foreign direct investment affected economic growth positively. In the study of Güney (2017), which used the variable of economic freedom as an indicator of globalization, it was found that economic freedom increased economic growth. 
Table 1: Globalization and Economic Growth Literature (Other Indicators)

\begin{tabular}{|c|c|c|c|c|c|c|c|c|c|}
\hline \multirow{2}{*}{ Study } & \multirow{2}{*}{ Term and Sample } & \multirow{2}{*}{ Method } & \multicolumn{7}{|c|}{ Result } \\
\hline & & & TO & $\mathbf{O P}$ & FD & IM & $\mathbf{E X}$ & FDI & $\mathbf{E F}$ \\
\hline $\begin{array}{l}\text { Afzal } \\
(2007)\end{array}$ & $\begin{array}{l}\text { 1960-2006 } \\
\text { Pakistan }\end{array}$ & VECM & $\varnothing$ & & $\varnothing$ & & & & \\
\hline $\begin{array}{l}\text { Yapraklı } \\
(2007)\end{array}$ & $\begin{array}{l}\text { 1990-2006 } \\
\text { Turkey }\end{array}$ & $\begin{array}{l}\text { Johansen } \\
\text { Cointegration and } \\
\text { Granger Causality. } \\
\text { Test }\end{array}$ & + & & - & & & & \\
\hline $\begin{array}{l}\text { Kıran and Güriş } \\
\text { (2011) }\end{array}$ & $\begin{array}{l}\text { 1992-2006 } \\
\text { Turkey }\end{array}$ & $\begin{array}{l}\text { ARDL and Toda- } \\
\text { Yamamoto } \\
\text { Causality.Test }\end{array}$ & + & & + & & & & \\
\hline $\begin{array}{l}\text { Türedi and } \\
\text { Berber } \\
(2010)\end{array}$ & $\begin{array}{l}\text { 1970-2007 } \\
\text { Turkey }\end{array}$ & $\begin{array}{l}\text { Johansen } \\
\text { Cointegration and } \\
\text { VAR Causality. } \\
\text { Analysis }\end{array}$ & $\leftrightarrow$ & & $\leftrightarrow$ & & & & \\
\hline $\begin{array}{l}\text { Neto and Veiga } \\
(2013)\end{array}$ & $\begin{array}{l}1970-2009 \\
139 \text { Countries }\end{array}$ & EKK-GMM & & & & & & + & \\
\hline $\begin{array}{l}\text { Ali and Imai } \\
(2015)\end{array}$ & $\begin{array}{l}\text { 1970-2009 } \\
41 \text { Countries }\end{array}$ & GMM & & + & + & & & & \\
\hline $\begin{array}{l}\text { Topallı } \\
(2015)\end{array}$ & $\begin{array}{l}\text { 1982-201 } \\
\text { BRICS-Turkey }\end{array}$ & $\begin{array}{l}\text { CADF Test, } \\
\text { Emirmahmutoğlu } \\
\text { and Köse Causality } \\
\text { Test }\end{array}$ & $\leftrightarrow$ & & & & & & \\
\hline $\begin{array}{l}\text { Ümit } \\
(2016)\end{array}$ & $\begin{array}{l}\text { 1989-2014 } \\
\text { Turkey }\end{array}$ & $\begin{array}{l}\text { ARDL, Toda- } \\
\text { Yamamoto } \\
\text { Causality.Test }\end{array}$ & - & & + & & & & \\
\hline $\begin{array}{l}\text { Manwa and } \\
\text { Wijeweera } \\
(2016)\end{array}$ & $\begin{array}{l}\text { 1980-2011 } \\
\text { Botswana, Lesotho, } \\
\text { Namibia, } \\
\text { South Africa and } \\
\text { Swaziland }\end{array}$ & ARDL & + & & & & & & \\
\hline $\begin{array}{l}\text { Gövdere and } \\
\text { Can } \\
(2016)\end{array}$ & $\begin{array}{l}\text { 1970-2011 } \\
\text { Turkey }\end{array}$ & ARDL & & + & $\varnothing$ & + & + & $\varnothing$ & \\
\hline $\begin{array}{l}\text { Örgün and Pala } \\
\text { (2017) }\end{array}$ & $\begin{array}{l}1996-2013 \\
28 \text { EU Countries }\end{array}$ & $\begin{array}{l}\text { Panel VECM and } \\
\text { Granger } \\
\text { Causality.Test }\end{array}$ & & $\leftrightarrow$ & & & & $\leftrightarrow$ & \\
\hline $\begin{array}{l}\text { Alvarado, } \\
\text { In1guez and } \\
\text { Ponce } \\
(2017)\end{array}$ & $\begin{array}{l}\text { 1980-2015 } \\
19 \text { Latin American } \\
\text { Countries }\end{array}$ & $\begin{array}{l}\text { Panel Rassal } \\
\text { Random Effects }\end{array}$ & & & & & & + & \\
\hline $\begin{array}{l}\text { Kartal and } \\
\text { Acaroğlu } \\
(2017)\end{array}$ & $\begin{array}{l}\text { 1961-2013 } \\
\text { Turkey }\end{array}$ & $\begin{array}{l}\text { EKK and Granger } \\
\text { Causality. Test }\end{array}$ & + & & & & & & \\
\hline $\begin{array}{l}\text { Güney } \\
(2017)\end{array}$ & $\begin{array}{l}\text { 1990-2014 } \\
\text { Turkey-BRICS }\end{array}$ & GEKK & & & & & & & + \\
\hline $\begin{array}{l}\text { Özcan et al. } \\
(2018)\end{array}$ & $\begin{array}{l}1992-2015 \\
18 \text { Emerging } \\
\text { Economy }\end{array}$ & $\begin{array}{l}\text { Emirmahmutoğlu- } \\
\text { Köse -Kónya } \\
\text { Causality test }\end{array}$ & $\rightarrow$ & & & & & & \\
\hline $\begin{array}{l}\text { Eren and Ergin } \\
\text {-Ünal } \\
(2019)\end{array}$ & $\begin{array}{l}\text { 1960-2016 } \\
\text { Turkey }\end{array}$ & $\begin{array}{l}\text { Toda-Yamamoto } \\
\text { Causality Test }\end{array}$ & $\leftrightarrow$ & & & & & & \\
\hline
\end{tabular}

TO :Trade Openness, OP: Openness, FD: Financial Development, IM: Import, EX: Export, FDI: Foreign Direct Investment, EF: Economic freedom, (Ø : Insignificant effect, +: Positive effect, - : Negative effect, $\leftrightarrow$ : Two-Way Relationship, $\rightarrow$ : One-way relationship).

The KOF globalization index, which was first used by Axel Dreher (2006), evaluates the globalization level of countries with a holistic approach and evaluates globalization 
economically, socially and politically. Continuous updating of the index and its economic, social and political inclusion are seen as useful aspects for evaluating globalization. Starting from 2006, this index has been used as an indicator of globalization in many studies. The studies using the KOF index evaluate the globalization-economic growth nexus, as well as the globalization-many economic factors nexus. In addition, the effects of EG, SG and PG, the subdimensions of globalization, on economic growth can be examined separately. A summary of the studies examining the connection between the sub-dimensions of globalization and economic growth is presented in Table 2 .

Table 2: Globalization and Economic Growth Literature (KOF Index)

\begin{tabular}{|c|c|c|c|c|c|c|}
\hline \multirow{2}{*}{ Study } & \multirow{2}{*}{ Term and Sample } & \multirow{2}{*}{ Method } & \multicolumn{4}{|c|}{ Result } \\
\hline & & & $G$ & $E G$ & $S G$ & $P G$ \\
\hline $\begin{array}{l}\text { Dreher } \\
(2006)\end{array}$ & $\begin{array}{l}1970-200 \\
123 \text { Countries }\end{array}$ & EKK-GMM & + & & & \\
\hline $\begin{array}{l}\text { Chang and Lee } \\
(2010)\end{array}$ & $\begin{array}{l}1970-2006 \\
23 \text { OECD Countries }\end{array}$ & FMOLS, VECM & & $\leftrightarrow$ & $\leftrightarrow$ & $\leftrightarrow$ \\
\hline $\begin{array}{l}\text { Chang and Lee } \\
\text { (2011) }\end{array}$ & $\begin{array}{l}1990-2016 \\
10 \text { Former Communist countries } \\
\text { and } 18 \text { OECD Countries }\end{array}$ & FMOLS, DOLS & + & & & \\
\hline $\begin{array}{l}\text { Sakyi } \\
(2011)\end{array}$ & $\begin{array}{l}1980-2005 \\
31 \text { African Countries }\end{array}$ & FMOLS, DOLS & + & & & \\
\hline $\begin{array}{l}\text { Rao and } \\
\text { Vadlamanti } \\
\text { (2011) }\end{array}$ & $\begin{array}{l}\text { 1970-2005 } \\
21 \text { Low Income African Countries }\end{array}$ & EKK-GMM & + & & & \\
\hline $\begin{array}{l}\text { Villaverde and } \\
\text { Maza } \\
(2011)\end{array}$ & $\begin{array}{l}1970-2005 \\
101 \text { Countries }\end{array}$ & GMM - EKK & + & + & + & + \\
\hline $\begin{array}{l}\text { Mutascu and } \\
\text { Anne-Marie } \\
\text { (2011) }\end{array}$ & $\begin{array}{l}\text { 1972-2006 } \\
\text { Romania }\end{array}$ & VAR analysis & + & & & \\
\hline $\begin{array}{l}\text { Osterloh } \\
(2012)\end{array}$ & $\begin{array}{l}197-2004 \\
23 \text { OECD Countries }\end{array}$ & EKK-GMM & $\varnothing$ & + & & \\
\hline $\begin{array}{l}\text { Chang et al. } \\
\text { (2013) }\end{array}$ & $\begin{array}{l}\text { 1990-2009 } \\
\text { Azerbaijan, Armenia, Georgia, } \\
\text { Turkey and Russia }\end{array}$ & EKK-GMM & & + & + & + \\
\hline $\begin{array}{l}\text { K1lıç } \\
(2015)\end{array}$ & $\begin{array}{l}\text { 1980-2011 } \\
74 \text { Developing Countries }\end{array}$ & $\begin{array}{l}\text { EKK- Granger } \\
\text { Causality.Test }\end{array}$ & & + & - & + \\
\hline $\begin{array}{l}\text { Gözgör and Can } \\
\text { (2016) }\end{array}$ & $\begin{array}{l}1970-2010 \\
139 \text { Countries }\end{array}$ & $\begin{array}{l}\text { Granger } \\
\text { Causality.Test }\end{array}$ & & $\leftrightarrow$ & & \\
\hline $\begin{array}{l}\text { Doğan and Can } \\
(2016)\end{array}$ & $\begin{array}{l}\text { 1970-2012 } \\
\text { South Korea }\end{array}$ & Dinamic EKK & + & + & + & \\
\hline $\begin{array}{l}\text { Olimpia and Stela } \\
(2017)\end{array}$ & $\begin{array}{l}\text { 1990-2013 } \\
\text { Romania }\end{array}$ & $\begin{array}{l}\text { EKK - Granger } \\
\text { Causality. Test }\end{array}$ & & + & - & + \\
\hline $\begin{array}{l}\text { K1liçarslan and } \\
\text { Dumrul } \\
(2018)\end{array}$ & $\begin{array}{l}\text { 1980-2015 } \\
\text { Turkey }\end{array}$ & FMOLS & & + & + & - \\
\hline $\begin{array}{l}\text { Midiyanti and } \\
\text { Ming-Hung } \\
\text { (2019) }\end{array}$ & $\begin{array}{l}\text { 1980-2014 } \\
\text { Indonesia }\end{array}$ & VECM & + & & & \\
\hline
\end{tabular}

G: General Globalization, EG: Economic Globalization, SG: Social Globalization, PG: Political Globalization, ( Ø: Insignificant effect, +: Positive Effect, - : Negative Effect, $\leftrightarrow$ : Two-Way Relationship)

In the studies using the KOF index, although different countries and groups of countries use different methods, Dreher (2006), Chang and Lee (2011), Sakyi (2011), Rao and Vadlamanti (2011), Mutascu and Anne-Marie (2011), Midiyanti and Ming-Hung (2019) concluded that general globalization rises economic growth. Villarde and Maza (2011), Chang 
et al. (2013) found that EG, SG and PG positively affected economic growth. K1liç (2015), Olimpia and Stela (2017) concluded that SG and Kiliçarslan and Dumrul (2018) concluded that PG negatively affected economic growth. In their study, Chang and Lee (2010) concluded that there is a bidirectional causal connection between EG, SG and PG and economic growth.

In most of the studies in the literature, trade openness, external openness, economic freedom, export and import variables have been used as globalization criteria. It is considered that the variables used do not measure the level of globalization comprehensively and focus on the economic dimension of globalization. The study differs from other studies in terms of using the KOF index, which comprehensively addresses the determination of the level of globalization with its economic, social and political dimensions, examines the BRICS-T countries that have an important development potential in the world economy, and evaluates the relationship between variables as a panel, as well as examining the relations between variables on a country basis.

\section{Model}

In this study, it is aimed to examine the effects of EG, SG and PG on real GDP of BRICS-T countries in the period 1990-2014. In this study, empirical models formed when transforming linear function formed on the basis of Coub-Douglas production function are formed as follows:

$$
\begin{array}{ll}
\text { Model 1: } & \ln G D P_{i t}=\delta_{0}+\delta_{1} \ln C_{i t}+\delta_{2} \ln E G_{i t}+u_{i t} \\
\text { Model 2: } & \ln G D P_{i t}=\gamma_{0}+\gamma_{1} \ln C_{i t}+\gamma_{2} \ln S G_{i t}+u_{i t} \\
\text { Model 3: } & \ln G D P_{i t}=\beta_{0}+\beta_{1} \ln C_{i t}+\beta_{2} \ln P G_{i t}+u_{i t}
\end{array}
$$

The labor variable $(\mathrm{L})$ in the Cobb-Douglas production function was excluded from the models due to the use of per-person values. (GDP) per capita national income, $(\mathrm{C})$ is per capita capital accumulation, (EG) is economic globalization, (SG) is social globalization, (PG) is political globalization and $u_{i t}$ is the term error.

\section{Data and Methodology}

Per capita income (GDP) is calculated in 2010 via the fixed US dollar. Per capita National Income data are obtained from World Bank WDI database. Capital Accumulation Per Capita (C) is the gross capital accumulation values calculated in 2010 via fixed prices. Data were obtained from World Bank WDI database. The EG KOF index consists of two subheadings: current flows (Foreign trade, Foreign Direct Investments, Portfolio Investments, Income Payments to Foreigners) and restrictions (Hidden Import Barriers, Average Customs Tariffs, International Trade Taxes, Capital Account Restrictions). The SG index consists of a combination of three subsections.: (SG) Personal Communication Data (Telephone traffic, Transfers, International Tourism, Foreign Population, International Letter), Information Flow (Internet Usage, Television, Newspaper Sales), Cultural Proximity Data (Number of McDonald Restaurants, Number of Ikea Stores, Book Sales). The PG index consists of the number of embassies in the country, membership in international organizations, participation in the UN Security Council and international agreements. Index values are evaluated over values between 0 and 100.

In this study, firstly the panel unit root tests are used to determine the stationarity levels of the variables. Secondly, panel cointegration tests are utilized to investigate the long-run relationship between the variables. Thirdly, panel coefficient estimator test is used to determine the direction and coefficient of the cointegration relationship of the variables. Lastly, The causality correlation between the variables is investigated by Dumitrescu-Hurlin (2012) causality test. 


\section{Empirical Results}

In this part of the study, the findings of the models created to analyze the impact of EG, SG and PG on economic growth in BRICS-T countries are given.

In panel data, it is important that the series be stationary as in the time series. Since the non-stationary series revealed false regression problems in the analyzes, first of all, it should be tested whether the series are stationary or not in order to obtain reliable results in panel data analysis. Levin, Lin and Chu (2002), Im, Pesaran and Shin (2003) and Breitung (2000) tests were used to test whether the variables were stationary or not. Unit root tests were applied for both level and first differences. The maximum latency lengths that resolve the autocorrelation problem between errors were determined by the Schwarz information criterion. In addition, the Newey-West bandwidth selection and the Bartlett Kernel method were used to calculate the LLC test.

Table 3: Panel Unit Root Test Results

\begin{tabular}{|c|c|c|c|c|c|c|}
\hline \multirow{2}{*}{ Level } & \multicolumn{2}{|c|}{ LLC } & \multicolumn{2}{|c|}{ IPS } & \multicolumn{2}{|c|}{ Breitung } \\
\hline & t-statistic & Probability & t-statistic & Probability & t-statistic & Probability \\
\hline $\operatorname{lnGDP}$ & $-2.113 * *$ & 0.017 & $-2.314 * * *$ & 0.010 & 1.298 & 0.902 \\
\hline $\ln C$ & $-1.861 * *$ & 0.031 & $-1.804 * *$ & 0.03 & -0.166 & 0.433 \\
\hline $\ln E G$ & $-2.564 * * *$ & 0.005 & $-1.341 * *$ & 0.089 & 0.201 & 0.579 \\
\hline $\operatorname{lnSG}$ & $-6.470 * * *$ & 0.000 & $-2.026 * *$ & 0.021 & 0.789 & 0.785 \\
\hline $\ln P G$ & $-3.941 * * *$ & 0.000 & $-3.656 * * *$ & 0.001 & 1.315 & 0.905 \\
\hline \multicolumn{7}{|c|}{ Difference Values } \\
\hline$\Delta \operatorname{lnGDP}$ & $-4.860 * * *$ & 0.000 & $-3.953 * * *$ & 0.000 & $-3.003 * * *$ & 0.001 \\
\hline$\Delta \ln C$ & $-6.653 * * *$ & 0.000 & $-4.813 * * *$ & 0.000 & $-3.806 * * *$ & 0.000 \\
\hline $\operatorname{lnEG}$ & $-6.151 * * *$ & 0.000 & $-6.799 * * *$ & 0.000 & $-4.970 * * *$ & 0.000 \\
\hline $\ln S G$ & $-7.711 * * *$ & 0.000 & $-5.567 * * *$ & 0.000 & $-6.979 * * *$ & 0.000 \\
\hline $\ln P G$ & $-9.229 * * *$ & 0.000 & $-9.987 * * *$ & 0.000 & $-2.926 * * *$ & 0.001 \\
\hline
\end{tabular}

Note: $\Delta$ : It shows the first difference of the series. $\left({ }^{* * *}\right)$ Significant at $1 \%$ level, $\left({ }^{* *}\right) 5 \%$ significant, $(*) 10 \%$ significant

Table 3 shows the results of the unit root test of the level and first differences of the variables. Of the three unit root tests used to determine the stationarity of the variables, LLC and IPS unit root tests showed that the variables were stationary at the level. However, in the Breitung unit root test, the variables were unit rooted. It is aimed to determine the same level of stationarity in all unit root tests used to continue the analysis. Therefore, it is seen that the variables whose differences are taken are stationary at $1 \%$ significance level according to the panel unit root tests.

When panel LM Unit Root Test with Structural Breaks results are examined in Table 4, the $\mathrm{H} 0$ hypothesis, which states that the series is unit rooted, is accepted for the level values of the variables. Differences of the variables were taken due to lack of series. As a result of the 
difference procedure, the hypothesis $\mathrm{H} 0$, which states that the series is unit rooted, was rejected and the series were found to be stationary.

Table 4: The Results of Panel LM Unit Root Test with Structual Breaks

\begin{tabular}{|c|c|c|c|c|c|}
\hline Countries & InGDP & $\ln C$ & InEG & InSG & InPG \\
\hline Brazil & 2002 & 2002 & 2000 & 1997 & 1993 \\
\hline Russia & 1997 & 1999 & 2004 & 1999 & 1995 \\
\hline India & 2004 & 2003 & 1994 & 1995 & 1993 \\
\hline China & 2006 & 1993 & 2007 & 1997 & 2006 \\
\hline South Africa & 2008 & 2007 & 1998 & 1994 & 1998 \\
\hline \multirow[t]{2}{*}{ Turkey } & 1999 & 1999 & 1995 & 2004 & 1995 \\
\hline & \multicolumn{2}{|c|}{ Level } & \multicolumn{3}{|c|}{ Difference Values } \\
\hline Variables & LM ist & Probability & Variables & LM ist & Probability \\
\hline InGDP & 0.438 & 0.669 & $\Delta \operatorname{lnGDP}$ & $-5.313^{* * *}$ & 0.000 \\
\hline $\ln C$ & 0.621 & 0.733 & $\Delta \ln C$ & $-7.551^{* * * *}$ & 0.000 \\
\hline InEG & -1.032 & 0.151 & $\Delta \operatorname{lnEG}$ & $-5.501^{* * *}$ & 0.000 \\
\hline InSG & 2.669 & 0.996 & $\Delta \operatorname{lnSG}$ & $-3.673^{* * *}$ & 0.000 \\
\hline InPG & -1.468 & 0.071 & $\Delta \ln P G$ & $-8.461^{* * *}$ & 0.000 \\
\hline
\end{tabular}

Note: $\Delta$ : It shows the first difference of the series. $* * *$ Significant at $1 \%$ level, $* * 5 \%$ significant, $* 10 \%$ significant.

When the breakdowns in variables are evaluated separately for countries, it is considered that Brazil's financial responsibility arrangements made in 2000 may cause breakdowns in national income per capita and capital accumulation per capita. It is thought that the breakdown in EG in 2000 may be caused by the Asian crisis that occurred in 1997, the breaks in SG in 1997 and in PG in 1993 may be caused by economic and political instability for the country that started in 1991.

It is considered that the breaks in Russia's PG variable in 1995 and per capita national income variable in 1997 could be due to the failure to achieve the desired success in the process of transition from the socialist system to the liberal system and the breaks in the capital accumulation per capita and the breaks in the SG variables in 1999 may be the reflection of the Asian Crisis in 1997. When the years of India's breakdown are analyzed, it is seen that there was a break in SG variable in 1995, in EG variable in 1994 and in PG in 1993. These breaks are thought to be caused by the stability and structural policies implemented after the economic crisis in 1991. It is considered that the breaks in the national income variable per capita in 2004 and the capital accumulation per capita in 2003 may be due to the increase in foreign direct investments as a result of the regulations made after 1991 together with the import and export legislation applied since 2002. When China's Panel LM Unit Root Test with Structual Breaks results are analyzed, it is thought that the SG variable was broken in 1997 and the reason was caused by the cooperation with Russia in various fields (education, health). It is considered that the break in the PG variable in 2006 is caused by reduced pressure exerted by the USA on the country and USA's bilateral agreements with non-member countries such as EU countries. It is thought that the economic crisis in 2007 caused the break in EG in the same year. It is thought that the break in the national income variable per capita in 2006 was caused by the growth strategy implemented after 2000, and the break in the capital accumulation variable per capita in 1993 could be caused by the increase in savings in the country since 1991. The break in the SG variable in South Africa in 1994 is thought to be due to the abandonment of democratic elections and racism policies in the country. On the other hand, the breakdown in political and EG in 1998 is attributed to the policies implemented by Mandela in the second period, and the breaks in national income and capital accumulation per capita may be caused by the global crisis of 2007. When Turkey examined along with the BRICS countries, it is thought that events such as the membership of the Organization of Black Sea Economic Cooperation in 1992, the 
initiation of customs union negotiations in 1993 and the economic crisis in 1994 were effective in the breakdowns in EG and PG in 1995. In addition, the Asian crisis occurred in 1997 is thought to be the source of the breakage occurred in 1999 in national income per capita in Turkey and in capital accumulation variable.

Table 5: Panel Cointegration Test Results

\begin{tabular}{lcccccc}
\hline \multirow{2}{*}{$\begin{array}{l}\text { Pedroni } \\
\text { Cointegration Test }\end{array}$} & \multicolumn{2}{c}{ Model I } & \multicolumn{2}{c}{ Model II } & \multicolumn{2}{c}{ Model III } \\
\cline { 2 - 7 } & $\begin{array}{c}\text { t- } \\
\text { statistics }\end{array}$ & Probability & $\begin{array}{c}\text { t- } \\
\text { statistics }\end{array}$ & Probability & $\begin{array}{c}\text { t- } \\
\text { statistics }\end{array}$ & Probability \\
\hline Panel v-statistics & $1.804^{* *}$ & 0.035 & $2.036^{* *}$ & 0.020 & $1.341^{*}$ & 0.089 \\
Panel rho-statistics & -0.760 & 0.223 & -0.771 & 0.220 & -0.538 & 0.295 \\
Panel PP-statistics & $-1.418^{*}$ & 0.078 & -1.203 & 0.114 & -0.993 & 0.160 \\
Panel ADF statistics & $-2.106^{* *}$ & 0.017 & $-2.187^{* *}$ & 0.014 & $-1.664^{* *}$ & 0.050 \\
Group rho-statistic & $0.188^{*}$ & 0.574 & 0.647 & 0.741 & 0.825 & 0.795 \\
Group PP statistic & $-0.987^{* *}$ & 0.016 & -0.092 & 0.463 & 0.018 & 0.507 \\
Group ADF statistics & $-3.434^{* * *}$ & 0.000 & $-1.595^{*}$ & 0.055 & -0.990 & 0.161 \\
\hline Kao Cointegration & \multicolumn{2}{c}{ Model I } & \multicolumn{2}{c}{ Model II } & Model III \\
\cline { 2 - 7 } Test & $\begin{array}{c}\text { t- } \\
\text { statistics }\end{array}$ & Probability & $\begin{array}{c}\text { t- } \\
\text { statistics }\end{array}$ & Probability & $\begin{array}{c}\text { t- } \\
\text { statistics }\end{array}$ & Probability \\
\hline Kao ADF & $-3.905^{* * *}$ & 0.000 & $-3.804^{* * *}$ & 0.000 & $-3.588^{* * *}$ & 0.000 \\
\hline
\end{tabular}

Note: $* * * 1 \%, * * 5 \%, *$ It shows a significant level of $10 \%$.

Panel unit roots were applied to the series and the stability of the series was tested and it was observed that the series were unit rooted at the first level and they were stationary. After finding that the series were stable, the long-term cointegration relationship of the series was investigated with the panel cointegration tests. Table 5 shows the results of panel cointegration tests. Although some of the seven statistics found to be significant according to the Pedroni cointegration test showed that there was a cointegration relationship between the series, Kao cointegration test was used as an alternative to support the results. The results of the Kao cointegration test showed that there was a $1 \%$ significance level of cointegration between the variables in the long run.

After determining the long-run cointegration relationship between the variables, the FMOLS (Edited Least Squares) method developed by Pedroni was used to determine the direction and degree of the long-term relationship. FMOLS estimation results for BRICS-T countries are shown in Table 6.

Table 6: FMOLS Estimation Results for BRICS-T Countries

\begin{tabular}{lccc}
\hline Variables & Model I & Model II & Model III \\
\hline $\operatorname{lnC}$ & $0.716^{* * *}[0.000]$ & $0.676^{* * *}[0.000]$ & $0.726 * * *[0.000]$ \\
$\operatorname{lnEG}$ & $0.139 * * *[0.000]$ & - & - \\
$\operatorname{lnSG}$ & - & $0.151 * * *[0.000]$ & - \\
$\ln P G$ & - & - & $0.068 * *[0.018]$ \\
\hline
\end{tabular}

Note: *** $1 \%, * * 5 \%, *$ It shows a significant level of $10 \%$. Values in parentheses represent probability values.

According to panel FMOLS estimation results, it is observed that $\operatorname{lnEG}$ for Model I, $\operatorname{lnSG}$ for Model II and lnPG for Model III increase economic growth at a level of $1 \%$ significance. Although different dimensions of globalization rise economic growth, it is seen 
that SG has the highest effect and PG has the lowest effect. In addition, although the coefficients are different, per capita capital accumulation $(\operatorname{lnC})$ enhances economic activities in all models.

The connection between independent variables and dependent variable is calculated by FMOLS coefficient estimation method in terms of the countries.

Table 7: BRICS-T Countries FMOLS Estimated Results

\begin{tabular}{|c|c|c|c|}
\hline Brazil & Model I & Model II & Model III \\
\hline $\ln C$ & $0.647 * * *[0.000]$ & $0.585^{* * *}[0.000]$ & $0.385 * * *[0.004]$ \\
\hline $\operatorname{lnEG}$ & $0.556^{* * *}[0.000]$ & - & - \\
\hline $\operatorname{lnSG}$ & - & $0.323^{* * *}[0.003]$ & - \\
\hline $\ln P G$ & - & - & $1.551 * * *[0.004]$ \\
\hline Russia & Model I & Model II & Model III \\
\hline $\ln C$ & $0.678 * * *[0.000]$ & $0.668 * * *[0.000]$ & $0.728 * * *[0.000]$ \\
\hline $\operatorname{lnEG}$ & $0.267 * * *[0.000]$ & - & - \\
\hline $\operatorname{lnSG}$ & - & $0.365^{* * *}[0.000]$ & - \\
\hline $\ln P G$ & - & - & $0.567 * * *[0.031]$ \\
\hline India & Model I & Model II & Model III \\
\hline $\ln C$ & $0.772 * * *[0.000]$ & $0.714 * * *[0.000]$ & $0.664 * * *[0.000]$ \\
\hline $\operatorname{lnEG}$ & $-0.074[0.828]$ & - & - \\
\hline $\operatorname{lnSG}$ & - & $0.044 \quad[0.415]$ & - \\
\hline $\ln P G$ & - & - & $0.647 \quad[0.332]$ \\
\hline China & Model I & Model II & Model III \\
\hline $\operatorname{lnC}$ & $0.087 * * *[0.000]$ & $0.792 * * *[0.000]$ & $0.793 * * *[0.000]$ \\
\hline $\operatorname{lnEG}$ & $0.091 \quad[0.685]$ & - & - \\
\hline $\operatorname{lnSG}$ & - & $0.075[0.231]$ & - \\
\hline $\ln \mathrm{PG}$ & - & - & $0.172[0.710]$ \\
\hline South Africa & Model I & Model II & Model III \\
\hline $\operatorname{lnC}$ & $0.442 * * *[0.000]$ & $0.480 * * *[0.000]$ & $0.419 * * *[0.000]$ \\
\hline $\operatorname{lnEG}$ & $0.304 * * *[0.001]$ & - & - \\
\hline $\operatorname{lnSG}$ & - & $0.144 * * \quad[0.030]$ & - \\
\hline $\ln P G$ & - & - & $0.100 * * *[0.000]$ \\
\hline Turkey & Model I & Model II & Model III \\
\hline $\ln C$ & $0.636^{* * *}[0.000]$ & $0.367 * * *[0.000]$ & $0.554 * * *[0.000]$ \\
\hline $\operatorname{lnEG}$ & $0.177 \quad[0.299]$ & - & - \\
\hline $\operatorname{lnSG}$ & - & $0.469 * * *[0.000]$ & - \\
\hline $\ln P G$ & - & - & $0.958 * *[0.011]$ \\
\hline
\end{tabular}

Note: $* * * 1 \%, * * 5 \%, * 10 \%$ level of significance. Values in parentheses represent probability values.

The relationship between PG and economic growth has been examined within the scope of Model III and the results are given in Table 6. In Model III, capital accumulation per capita in all countries has a positive effect on economic growth. In Brazil, Russia, South Africa and Turkey, PG is seen to have a positive effect on economic growth. PG of the countries with the highest coefficient are Brazil $(1,551)$ and Turkey (0.958) Although these countries have made great progress in terms of political relations in recent years, China's problems with some countries such as the US and India's conflicts with various countries such as Pakistan, may lead to negative consequences for the impact of PG. 
Table 8: Dumitrescu-Hurlin Granger Causality Test Results

\begin{tabular}{lccc}
\hline \multicolumn{1}{c}{ Zero Hypothesis } & Wald statistics & Z-bar statistics & Probability \\
\hline $\ln C \rightarrow \ln G D P$ & 5.086 & 2.723 & $0.006^{* * *}$ \\
$\ln G D P \rightarrow \ln C$ & 14.655 & 11.910 & $0.000^{* * *}$ \\
$\ln E G \rightarrow \ln G D P$ & 9.402 & 6.867 & $0.000^{* * *}$ \\
$\ln G D P \rightarrow \ln E G$ & 1.657 & -0.569 & 0.569 \\
$\ln S G \rightarrow \ln G D P$ & 4.615 & 2.271 & $0.023^{* *}$ \\
$\ln G D P \rightarrow \ln S G$ & 3.162 & 0.876 & 0.380 \\
$\ln P G \rightarrow \ln G D P$ & 5.637 & 3.252 & $0.001^{* * *}$ \\
$\ln G D P \rightarrow \ln P G$ & 5.077 & 2.714 & $0.006^{* * *}$ \\
\hline
\end{tabular}

Note: The delay length (K) 2 is taken. *** $1 \%, * * 5 \%, *$ It shows a significant level of $10 \%$.

The results of the panel causality test are presented in Table 7. According to Table 7, it is seen that there is a bidirectional causality relationship between $\operatorname{lnC}$ and $\operatorname{lnGDP}$ at $1 \%$ significance level. In addition, there are one-way causalities from $\operatorname{lnEG}$ and $\ln S G$ to $\operatorname{lnGDP}$ variables. Furthermore, there is a two-way causality relationship between lnPG and lnGDP.

\section{Conclusions}

The effects of globalization are generally evaluated in economic term with ignoring the socially and politically impacts. However, undoubtedly, while the economy is the most affected by globalization, it also leads to many changes in the social and political spheres. In addition to the benefits provided to countries of different sizes, these changes may have some negative effects. Within the scope of our research, the effects of the sub-dimensions of globalization on economic growth in the countries studied were investigated.

The analyzes conducted in this study aim to reveal the effects of EG, SG and PG on economic growth for the period between 1990 and 2014 in BRICS-T countries. The findings of the analysis show that EG, SG and PG has a positive effect on economic growth in BRICS-T countries. When we compare the relative effects of globalization with sub-dimensions, it seen that the SG has the highest positive impact on growth, while the PG has lowest impact. Since the model established in the study was based on the Cobb-Douglas production function, it was obtained that the capital accumulation per capita in the model has a positive effect on economic growth. It is seen that the findings obtained in the study are compatible with the studies of Villarde and Maza (2011), Osterloh (2012), Chang et al and Doğan and Can (2016). The results of our study are not consistent with the studies of Kılıç (2015) and Olimpia and Stela (2017), who concluded that the impact of SG on economic growth was negative, and Kilıçarslan and Dumrul (2018), which concluded that the impact of PG on economic growth was negative. This situation is considered to be caused by differences in the countries studied or by the different methods used. Because the FMOLS coefficient estimation results of the countries examined within the scope of our study confirm this situation.

When the FMOLS coefficient estimation results examined according to countries, EG, SG and PG did not have a statistically significant effect on the economic growth of China and India. It is considered that the reason for the results of this country to be insignificant may be the evaluation of liberalization and restrictions together in the content of the KOF index used. In addition, the lack of expected economic freedom in these countries, the non-tariff barriers and import bans applied are considered to have a negative impact on the globalization of countries. When the analysis results of other countries are evaluated, it is seen that the effect of EG, SG and PG on economic growth is positive in Brazil, Russia and South Africa. According to Turkey's analysis, EG statistically insignificent in terms of the impact on economic growth while the effect of PG is seen as positive and high. 
When evaluating the results of the analysis, the concentration of Turkey's social and political dimensions of globalization is seen to provide a positive impact on country's economic growth. In China and India, social and economic rights within the country should be regulated, freedoms should be increased and domestic laws should be transformed in line with international norms. Moreover, it is considered that following an inclusive and solutionoriented strategy in international politics will be positive in terms of PG. According to the analysis results of Brazil, Russia and South Africa, EG, SG and PG have positive effects on economic growth, albeit at different levels. In this respect, it is seen that Brazil's concentration on PG, Russia's concentration on SG and the concentration of South Africa on EG may have more impact on the economic growth of countries.

\section{References}

Afzal, M. (2007). The impact of globalization on economic growth of Pakistan. The Pakistan Development Review, 46 (4-2), 723-734.

Ali, A. \& Imai, K. S. (2015). Crises, economic integration and growth collapses in African countries. Journal of African Economies, 24 (4), 471-501. doi.org/10.1093/jae/ejv010

Alvarado, R. Iñiguez, M., Ponce, P. (2017). Foreign direct investment and economic growth in Latin America. Economic Analysis and Policy, 56, 176-187. doi.org/10.1016/j.eap.2017.09.006

Breitung, J. \& Das, S. (2005). Panel unit root tests under cross sectional dependence. Statistica Neerlandica, 59 (4), 414-433. doi.org/10.1111/j.1467-9574.2005.00299.x

Chang, C. P. \& Lee, C. C. (2011). The effect of globalization and political party on economic growth: panel data analysis of former communist countries and European OECD members, Eastern European Economics, 49 (6), 5-26. https://doi.org/10.2753/EEE0012-8775490601

Chang, C. P., Berdiev, A. N., Lee, C. C. (2013). Energy exports, globalization and economic growth: the case of south caucasus. Economic Modelling, 33, 333-346. https://doi.org/10.1016/j.econmod.2013.04.027

Chang, C.P. \& Lee, C.C. (2010). Globalization and economic growth: a political economy analysis for OECD countries, Global Economic Review, $39 \quad$ (2), 151.173. https://doi.org/10.1080/1226508X.2010.483835

Doğan, B. (2017). Relationship between economic globalization and growth: toda-yamamoto causality analysis in the case of Turkey. Journal of Finance-Political \& Economic Comments, 54 (628), 19-27.

Doğan, B. \& Can, M. (2016). The effect of globalization on growth: cointegration analysis for the sample of South Korea. Journal of The Faculty of Economics and Administrative Sciences, 6 (2), 197-220.

Dreher, A. (2006). "Does globalization affect growth? evidence from a new index of globalization", Applied Economics, 38 (10), 1091-1110. https://doi.org/10.1080/00036840500392078

Dumitrescu, E. I. \& Hurlin C. (2012). Testing for granger non-causality in heterogeneous panels, Economic Modelling, 29 (4), 1450-1460. https://doi.org/10.1016/j.econmod.2012.02.014

Eren, M. V. \& Ergin, Ü. A. (2019). Analysis of the relationship between trade openness and economic growth: the case of Turkey Sosyoekonomi, 27 (39), 81-93. https://doi.org/10.17233/sosyoekonomi.2019.01.05

Gövdere, B. \& Can, M. (2016). The effects of energy consumption, openness, financial development, capital formation and foreign trade on economic growth in Turkey: bounds testing approach, Niğde University Journal of The Faculty of Economics and Administrative Sciences, 9 (1), 209228.

Gözen, R. (2004). Post-international relations pluralism, globalization and september 11, 1st Edition, Alfa Publications, İstanbul. 71-72. 
Gözgör, G. \& Can, M. (2017). Causal linkages among the product diversification of exports, economic globalization and economic growth. Review of development economics, 21 (3), 888-908. https://doi.org/10.1111/rode.12301

Güney, T. (2017). The impact of economic freedom on economic growth in Turkey and BRICS countries, International Review Of Economics and Management, 5 (2), 20-38. https://doi.org/10.18825/iremjournal.315949

Im, K. S., Lee, J., Tieslau, M. (2005). Panel LM unit-root tests with level shifts. Oxford Bulletin of Economics and Statistics, 67 (3), 393- 419. https://doi.org/10.1111/j.1468-0084.2005.00125.x

Im, K. S., Pesaran, M. H., Shin, Y. (2003). Testing for unit roots in heterogeneous panels. Journal of Econometrics, 115 (1), 53-74. https://doi.org/10.1016/S0304-4076(03)00092-7

Kao, C. (1999). "Spurious regression and residual-based tests for cointegration in panel data", Journal of Econometrics, 90 (1), 1-44. https://doi.org/10.1016/S0304-4076(98)00023-2

Kartal, Z. \& Acaroğlu, H. (2017). Global economy and Turkey: The measurement of the globalization's level, its property and its effects to the economic growth in the duration of integration to the global economy, 1961-2013. Pamukkale University Journal of Social Sciences Institute, 26, 152-177.

K1lıç, C. (2015). Effects of globalization on economic growth: panel data analysis for developing countries. Petroleum-Gas University of Ploiesti Bulletin, Technical Series, 67 (1), 1-11.

Kıran, B. \& Güriş, B. (2011). Business and financial growth impact openness in Turkey: a study on the 1992-2006 period, Anadolu University Journal of Social Sciences, 11(2), 69-80.

Levin, A., C.F. Lin, C. Chu, (2002). Unit root test in panel data: asymptotic and finite sample properties, Journal of Econometrics 108, 1-25. https://doi.org/10.1016/S0304-4076(01)00098-7

Manwa, F. \& Wijeweera, A. (2016). Trade liberalization and economic growth link: the case of Southern African Custom Union countries. Economic Analysis and Policy, 51, 12-21. https://doi.org/10.1016/j.eap.2016.05.001

Midiyanti, R. \& Yao, M. H. (2019). The dynamic relationship between globalization and economic growth: its implication on business policy. International Journal of Applied Business Research. $l$ (2), 100-111. https://doi.org/10.35313/ijabr.v1i02.49

Mutascu, M. \& Fleischer, A. M. (2011). Economic growth and globalization in Romania. World Applied Sciences Journal, 12 (10), 1691-1697.

Neto, D. G. \& Veiga, F. J. (2013). Financial globalization, convergence and growth: the role of foreign direct investment. Journal of International Money and Finance, 37, 161-186. https://doi.org/10.1016/j.jimonfin.2013.04.005

Olimpia, N. \& Stela, D. (2017). İmpact of globalization on economic growth in Romania: an empirical analysis of its economic, social and political dimensions. Studia Universitatis ,Vasile Goldis” Arad-Economics Series, 27 (1), 29-40. https://doi.org/10.1515/sues-2017-0003

Örgün, B. O. \& Pala, A. (2017). The relationship between energy consumption, trade openness and economic growth: panel granger causality analysis for EU-28 countries. Finance Political \& Economic Commentary, 54 (623), 9-20.

Osterloh, S. (2012). Words speak louder than actions: the impact of politics on economic performance. Journal of Comparative Economics, 40 (3), 318-336. https://doi.org/10.1016/j.jce.2012.05.004

Özcan, C. C., Özmen, İ., Özcan, G. (2018). Causality relationship between trade openness and economic growth: emerging market economies. Selçuk University Journal of Social Sciences Institute, 40. 60-73.

Pedroni, P. (1999). "Critical values for cointegration tests in heterogeneous panels with multiple regressors", Oxford Bulletin of Economics and Statistics, 61(1), 653- 570. https://doi.org/10.1111/1468-0084.0610s1653 
Pedroni, P. (2001). "Fully modified OLS for heterogeneous cointegrated panels", Baltagi, B.H., Fomby, T.B. and Carter Hill, R. (Ed.) Nonstationary Panels, Panel Cointegration, and Dynamic Panels Advances in Econometrics, Vol. 15, 93-130: Emerald Group Publishing Limited, Bingley, https://doi.org/10.1016/S0731-9053(00)15004-2

Pedroni, P. (2001). "Purchasing power parity tests in cointegrated panels", Review of Economics and Statistics, 83, 727-931. https://doi.org/10.1162/003465301753237803

Pedroni, P. (2004). "Panel cointegration, asymptotic and finite sample properties of pooled time series tests with an application to the purchasing power parity hypothesis", Econometric Theory, 20 (3), 597-625.

Rao, B. B. \& Vadlamannati, K. C. (2011). Globalization and growth in the low income African countries with the extreme bounds analysis. Economic Modelling, 28 (3), 795-805. https://doi.org/10.1016/j.econmod.2010.10.009

Sakyi, D. (2011). Economic globalization, democracy and income in Sub-Saharan Africa: a panel cointegration analysis, Proceedings of the German Development Economics Conference, Berlin, $72,1-34$

Swiss Economic Institute, KOF index https://kof.ethz.ch/en/forecasts-and-indicators/indicators/kofglobalisation-index.html (Erişim Tarihi: 11.05.2020)

Tekbaş, M. (2019). Investigation Of Globalization And Economic Growth Relations With Different Dimensions In BRICS-T Countries, PhD. Published Thesis, Gaziantep University Institute of Social Sciences, Gaziantep.

Topall, N. (2016). Direct capital investment, the relationship between trade openness and economic growth: the example of Turkey and the BRICS countries. Dogus University Journal, 17 (1), 8395.

Türedi S. \& Berber M. (2010). Financial development, trade relations between openness and economic growth: an analysis on Turkey, Erciyes University Journal of Economics and Administrative Sciences, 35, 301-316.

Ümit, A. Ö. (2016). Trade openness in Turkey, the relationship between financial openness and economic growth: the limit test approach. Journal of Ömer Halisdemir University Faculty of Economics and Administrative Sciences, 9 (1), 255-272.

Villaverde, J. and Maza, A. (2011). Globalization, growth and convergence. The World Economy, 34 (6), 952-971.

World Bank, (2019). https://data.worldbank.org/indicator (Erişim Tarihi: 11.05.2020).

Yaprakl1, S. (2007). Openness with business and financial relationship between economic growth: an application Turkey. Istanbul University Faculty of Economics e-Journal of Econometrics and Statistics, 5, 67-89.

Zerrin, K. \& Dumrul, Y. (2018). the impact of globalization on economic growth: empirical evidence from the Turkey. International Journal of Economics and Financial Issues, 8 (5), 115-123. 